\title{
Effect of Aspergillus spp. on Seed Quality Characters of Groundnut
}

\author{
N. Aiswarya, S.L. Bhattiprolu, K. Bayyapu Reddy, G. Rama Rao
}

10.18805/IJARe.A-5683

\begin{abstract}
Background: Aspergillus niger and A. flavus cause rotting, damping-off, loss in germination and toxification of oil seeds. Aspergillus is a common mold in tropical and Sub-tropical countries and causes aflatoxin contamination. $A$. flavus and $A$. niger were responsible for storage rot of groundnut. In addition to storage rot, aflatoxin contamination also leads to adverse effects on consumer health. Therefore, present study was conducted to estimate the impact of both $A$. niger and $A$. flavus on seed quality parameters of groundnut. Methods: Effect of major seed borne fungi A.niger and $A$. flavus on seed quality characters of thirteen different genotypes of groundnut was observed in the present study. All the seedling quality characters were measured as per ISTA guidelines.

Result: On an average $A$. niger caused 25.14, 25.18, 43.99, 26.20 and 44.75 per cent reduction in seed germination, seedling length, seedling vigour index I, seedling dry weight and seedling vigour index II, respectively, over the control whereas $A$. flavus caused average per cent reduction of $22.38,24.23,41.18,23.92$ and 40.95 in seed germination, seedling length, seedling vigour index I, seedling dry weight and seedling vigour index II, respectively, over the control.
\end{abstract}

Key words: Aspergillus flavus, A. niger, Germination, Groundnut, Seed quality characters.

\section{INTRODUCTION}

Groundnut is an important crop and is considered as the king of oil seeds. It is cultivated globally in 26.4 million hectares with a total production of 37.1 million tonnes. India ranks first in area with coverage of about 70 lakh hectares in acreage and second in production with an output of about 85 lakh tones (IOPEPC Survey of Groundnut Crop, Kharif-2017).

Of the various biotic stresses, seed borne and soil borne diseases account for most of the reduced pod yields. Fungal diseases such as collar rot caused by $A$. niger and storage rot caused by $A$. flavus result in major losses. Hence the present studies were carried out to study the influence of major seed borne fungi $A$. niger and $A$. flavus on the seed quality characters of thirteen different genotypes of groundnut.

\section{MATERIALS AND METHODS}

The present investigation was carried out in the laboratory of Plant Pathology, Regional Agricultural Research Station, Lam and the Department of Seed Science and Technology, Advanced Post Graduate Centre, Lam, Guntur, Andhra Pradesh during 2018-2019. Apparently healthy seed of groundnut cultivars were surface sterilized and soaked in conidial suspension of $A$. niger and $A$. flavus containing $10^{6} \mathrm{conidia} \mathrm{ml}^{-1}$ for $20 \mathrm{~min}$ and dried at room temperature overnight. The seeds of control treatments were similarly treated except that they were soaked in sterile distilled water.

The inoculated seed and control (uninoculated) seeds were kept for germination using rolled paper towel method in four replications of hundred seeds each and the following observations were recorded.
Department of Seed Science and Technology, Advanced Post Graduate Centre, Regional Agricultural Research Station, Acharya N.G. Ranga Agricultural University, Lam, Guntur-522 034, Andhra Pradesh, India.

Corresponding Author: N. Aiswarya, Department of Seed Science and Technology, Advanced Post Graduate Centre, Regional Agricultural Research Station, Acharya N.G. Ranga Agricultural University, Lam, Guntur-522 034, Andhra Pradesh, India. Email: aiswaryanayani@gmail.com

How to cite this article: Aiswarya, N., Bhattiprolu, S.L., Reddy, K.B. and Rao, G.R. (2021). Effect of Aspergillus spp. on Seed Quality Characters of Groundnut. Indian Journal of Agricultural Research. DOI: 10.18805/IJARe.A-5683.

Submitted: 16-09-2020 Accepted: 10-05-2021 Online: 06-09-2021

\section{Germination (\%)}

On $10^{\text {th }}$ day (final count), all the normal seedlings were counted. The germination percentage from each sample in each replication was computed as per the formula mentioned here under:

$$
\text { Germination }(\%)=\frac{\text { Number of normal seedlings }}{\text { Total number of seed sown }} \times 100
$$

\section{Seedling length $(\mathrm{cm})$}

Ten normal seedlings were taken from each sample at random on the $10^{\text {th }}$ day and the seedling length was measured from the tip of the primary leaf to the tip of the primary root with the help of a scale and was expressed in centimeters. 


\section{Seedling dry weight $(\mathbf{g})$}

Ten normal seedlings were taken from each sample at random on the $10^{\text {th }}$ day and the seedling dry weight was measured after drying them in a hot air oven at $75 \pm 1^{\circ} \mathrm{C}$ for 48 hours and mean seedling dry weight was expressed in grams.

\section{Seedling vigour index I}

Seedling vigour index I was computed using the following formula given by Abdul Baki and Anderson (1973).

Seedling vigour index $\mathrm{I}=$

Germination (\%) $\times$ Mean seedling length $(\mathrm{cm})$

\section{Seedling vigour index II}

Seedling vigour index II was computed using the following formula suggested by Reddy and Khan (2001) as given below:

Seedling vigour index $\|=$

Germination (\%) × Mean seedling dry weight $(\mathrm{g})$

\section{RESULTS AND DISCUSSION}

\section{Germination}

Significant variation was observed in germination between the uninoculated and inoculated samples irrespective of the genotype. The germination ranged between 64 (Dharani) and 84.5 (TAG 24) in seeds inoculated with $A$. flavus and 62 (Dharani) to 83.75 (TAG 24) in seeds inoculated with $A$. nigeras against 88 (Dharani) and 97.75 (TAG24) in control. The average germination of 91.42 per cent in control decreased to 70.90 and 69.09 due to inoculation with $A$. flavus and $A$. niger, respectively (Table 1 ).

Maximum per cent reduction in germination of 30.14 was recorded in Amaravati followed by Dharani (29.55) due to $A$. niger. Similar trend was noticed in seeds inoculated with $A$. flavus. Minimum reduction in germination was recorded in TAG 24 in both $A$. niger and $A$. flavus inoculated seeds (Fig 1).

The reduction in germination is due to release of mycotoxins like aflatoxin by the fungus which interfere with enzymatic activity and damages the developing embryo. Decrease in germination due to inoculation with Aspergillus spp. was observed in wheat by Harman and Pfleger (1974) and Sauer (1988). The germination of $90 \%$ in maize decreased to 72,85 and $80 \%$ due to $A$. flavus in local variety, Vijay and VL-16, respectively (Paul, 1991). Kakde and Chavan (2010) also observed decrease in germination in soybean due to inoculation with $A$. flavus. Deepavali and Nilima (2014) observed that maize seeds soaked in the culture filtrate of $A$. niger, showed germination decreased from $80 \%$ to $20 \%$ in African tall and $100 \%$ to $40 \%$ in Amber.

\section{Seedling length $(\mathrm{cm})$}

Seedling length varied significantly between the uninoculated and inoculated samples irrespective of genotype. The seedling length ranged between $12.52 \mathrm{~cm}$ (TCGS 1616) and $24.78 \mathrm{~cm}$ (TAG 24) in seeds inoculated with $A$. flavus and $12.26 \mathrm{~cm}$ (TCGS 1616) and $24.63 \mathrm{~cm}$
(TCGS 1616) in seeds inoculated with $A$. Niger as against $16.82 \mathrm{~cm}$ (Dharani) and $31.52 \mathrm{~cm}$ (TAG 24) in control. Highest seedling lengths of $24.63 \mathrm{~cm}$ and $24.78 \mathrm{~cm}$ were recorded in TAG 24 inoculated with $A$. niger and $A$. flavus, respectively followed by TCGS 1073 with $21.41 \mathrm{~cm}$ and $20.58 \mathrm{~cm}$ respectively while the uninoculated TAG 24 and TCGS 1073 showed $31.52 \mathrm{~cm}$ and 28.33 am, respectively. Lowest seedling lengths of $12.26 \mathrm{~cm}$ and $12.52 \mathrm{~cm}$ were expressed in TCGS 1616 due to inoculation with $A$. niger and $A$. flavus, respectively (Table 1 ).

The average seedling length decreased from $20.93 \mathrm{~cm}$ in control to $16.06 \mathrm{~cm}$ and $16.17 \mathrm{~cm}$ due to inoculation with $A$. niger and $A$. flavus respectively. The maximum per cent reduction in seedling length due to $A$. niger was recorded in TCGS 1616 (37.42\%) followed by Kadiri $6 n(28.46 \%)$. Similar results were recorded in seeds inoculated with $A$. flavus. The lowest per cent reduction of 13.45 and 12.92 due to inoculation with $A$. niger and $A$. flavus respectively was recorded in Narayani (Fig 2).

The reduction in seedling length might be due to the utilization of energy rich compounds by the fungi which are otherwise translocated to the seedling for their growth. Increase in the concentration of aflatoxins also decreased seed shoot growth in pulses (Janardhan et al. 2011). Deepavali and Nilima (2014) observed shoot length in African tall seed treated with the culture filtrate of $A$. niger decreased from $38.3 \mathrm{~cm}$ to $36 \mathrm{~cm}$, whereas Amber seed showed no decrease in shoot length. Paul (1991) observed the effect of $A$. flavus on seed quality of three varieties of maize. Seedling length decreased significantly from $37 \mathrm{~cm}$ to $22.9 \mathrm{~cm}$ in local variety and $28 \mathrm{~cm}$ to $20 \mathrm{~cm}$ in VL-16 while it is not significant in Vijay.

\section{Seedling vigour index I}

Significant decrease in both germination and seedling length of different groundnut genotypes after inoculation with Aspergillus spp. resulted in the decrease of seedling vigour index I. The seedling vigour index I ranged between 877 (Dharani) and 2094 (TAG 24) in seeds inoculated with $A$. flavus and 841 (Dharani) and 2063 (TAG 24) in seeds inoculated with $A$. niger as against 1480 (Dharani) and 3081 (TAG 24) in control (Table 1).

The average seedling vigour index I of 1920 decreased to 1158 and 1123 due to inoculation with $A$. flavus and $A$. niger respectively. The maximum per cent reduction in seedling vigour index I due to $A$. nigerwas recorded in TCGS 1616 followed by Amaravati. Similar results were recorded in seeds inoculated with $A$. flavus. The minimum per cent reduction in seedling vigour index I of 33.04 and 32.04 due to $A$. niger and $A$. flavus respectively was recorded in TAG 24 (Fig 3).

Aspergillus niger and Fusarium spp. are associated with damage of plumule and hypocotyl of germinating seedling which consequently lead to the reduction of germination and seedling length which consequently leads to reduction in seedling vigour index I (Akonda et al. 2016). Begum et al. (2013) reported decrease in seedling vigour index I of groundnut 


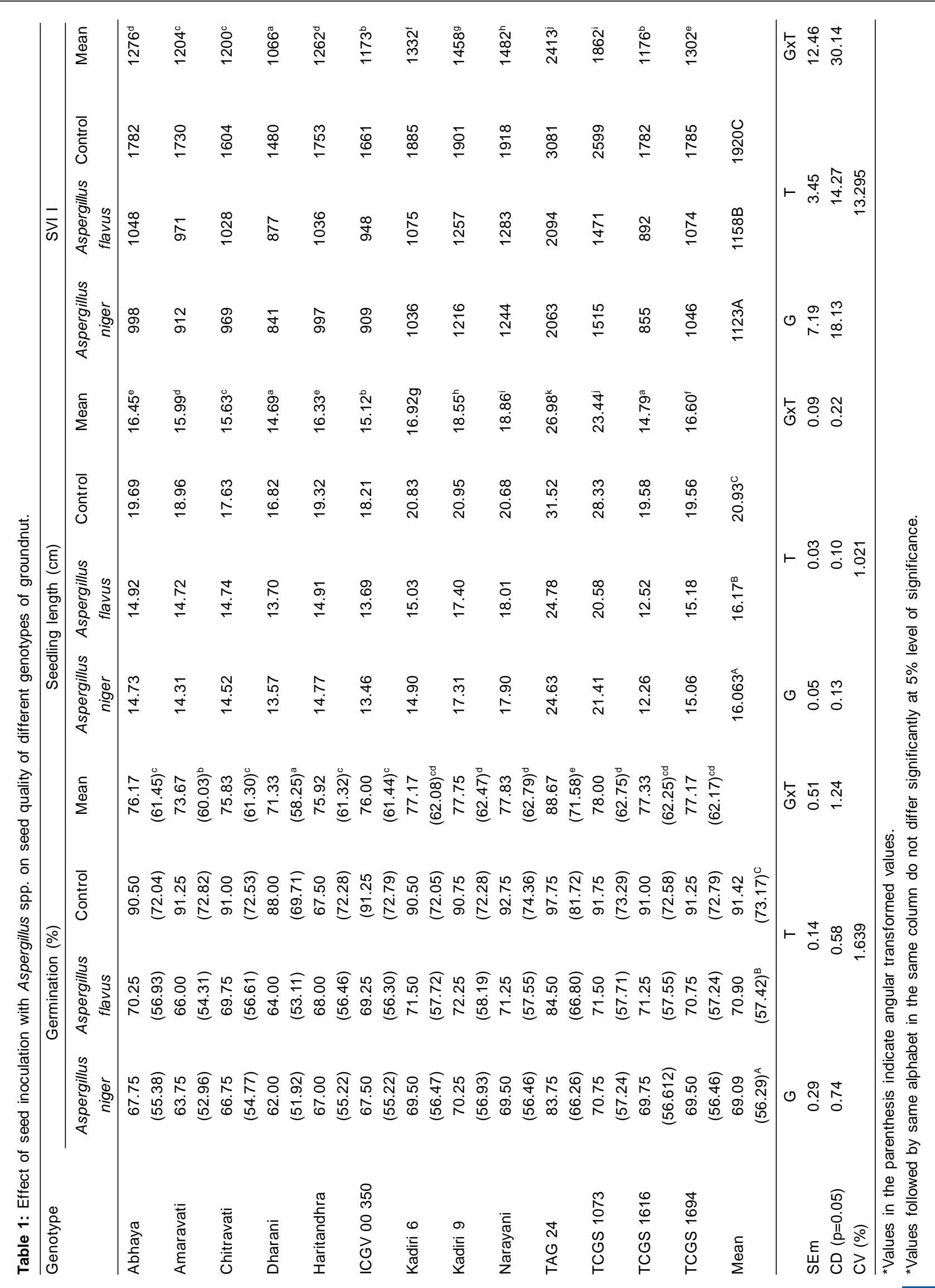




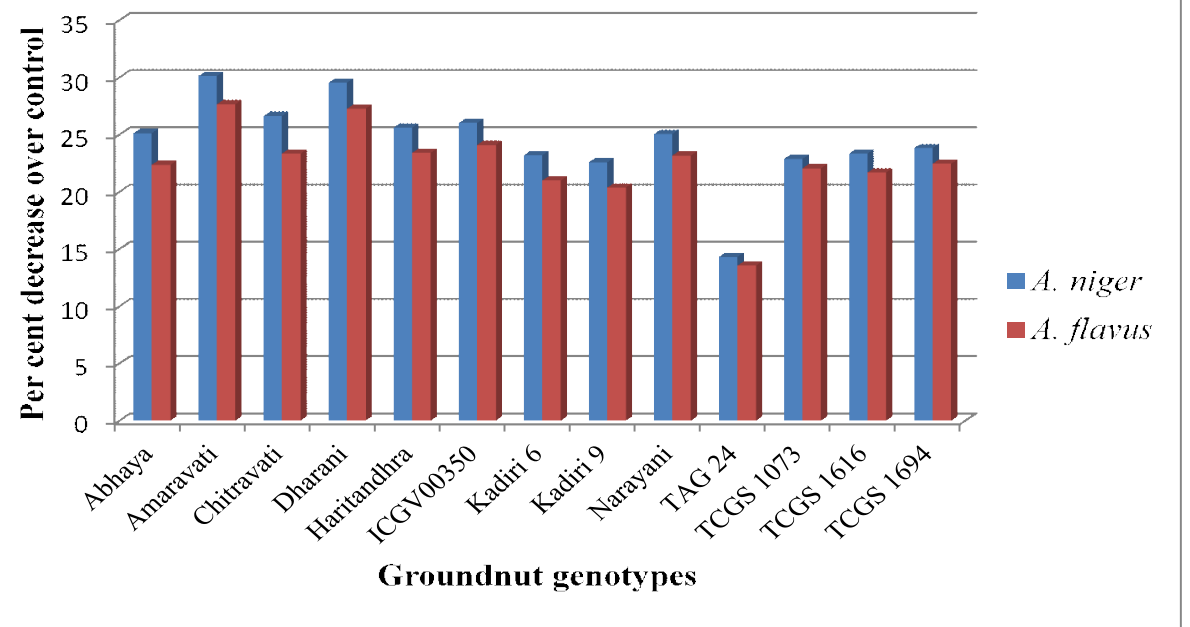

Fig 1: Per cent decrease in germination over control due to Aspergillus spp.

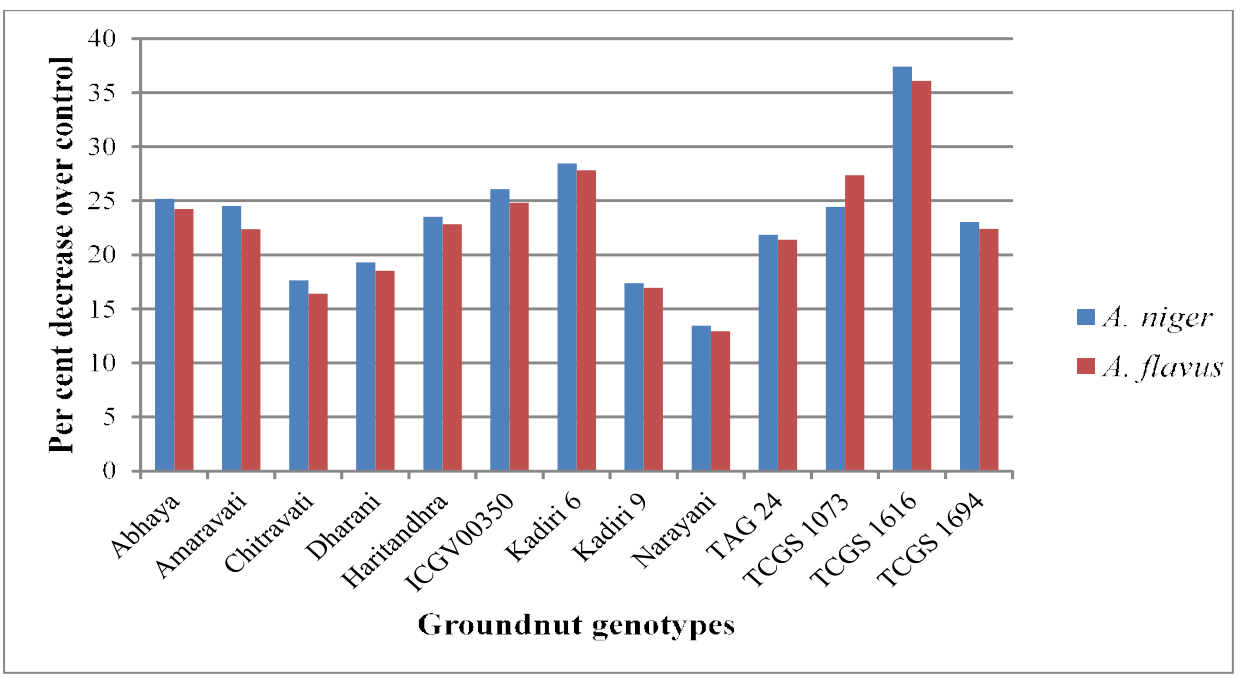

Fig 2: Per cent decrease in seedling length over control due to Aspergillus spp.

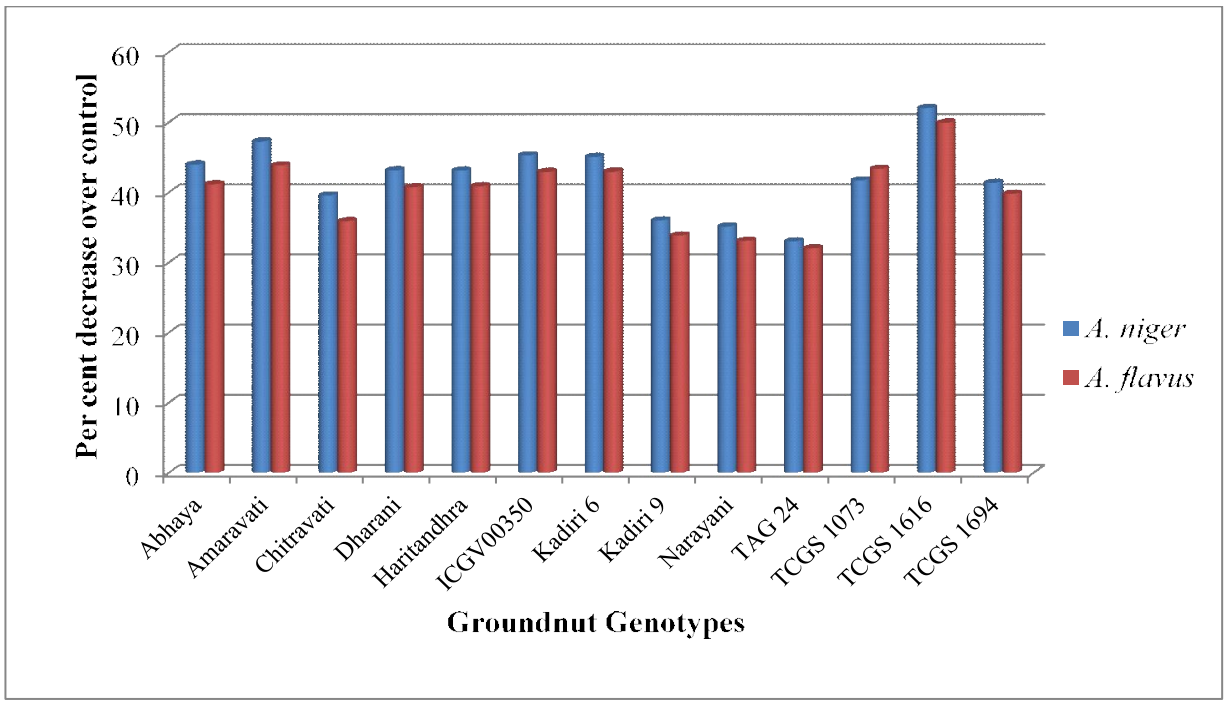

Fig 3: Per cent decrease in seedling vigour index I over control due to Aspergillus spp. 
seed inoculated with A. Flavus. Rohtas et al. (2016) studied the effect of collar rot fungus, $A$. niger in four groundnut genotypes viz., $\mathrm{MH}-4, \mathrm{MH}-21, \mathrm{M}-522$ and HNG-10. MH-1 showed maximum per cent reduction in germination $(20 \%)$, plumule length $(25.18 \%)$, radical length $(23.9 \%)$, fresh weight $(34.02 \%)$ and dry weight $(37.93 \%)$ whereas HNG10 showed minimum per cent reduction for all the above seed quality characters.

\section{Seedling dry weight (g)}

Significant reduction in seedling dry weight was observed in seed samples inoculated with both $A$. niger and $A$. flavus.
The seedling dry weight ranged between $0.165 \mathrm{~g}$ (Dharani) and $0.245 \mathrm{~g}$ (TCGS 1073) in seed inoculated with $A$. flavus and between 0.139 (ICGV 00 350) and $0.246 \mathrm{~g}$ (TCGS 1073) in seed inoculated with $A$. niger as against $0.184 \mathrm{~g}$ and $0.306 \mathrm{~g}$ in control (Table 2).

The average seedling dry weight decreased from 0.238 $\mathrm{g}$ in control to $0.184 \mathrm{~g}$ and $0.193 \mathrm{~g}$ in seeds inoculated with $A$. niger and $A$. flavus, respectively. The maximum per cent reduction in seedling dry weight due to $A$. nigerwas recorded in Amaravati (36.05\%) followed by ICGV 00350 (32.44\%). The maximum per cent reduction in seedling dry weight due to A. flavus was recorded in Amaravati (27.70\%)

Table 2: Effect of seed inoculation with Aspergillus spp. on seed quality of different genotypes of groundnut.

\begin{tabular}{|c|c|c|c|c|c|c|c|c|}
\hline \multirow[b]{2}{*}{ Genotype } & \multicolumn{3}{|c|}{ Seedling dry weight $(\mathrm{g})$} & \multicolumn{5}{|c|}{ SVI II } \\
\hline & $\begin{array}{c}\text { Aspergillus } \\
\text { niger }\end{array}$ & $\begin{array}{l}\text { Aspergillus } \\
\text { flavus }\end{array}$ & Control & Mean & $\begin{array}{l}\text { Aspergillus } \\
\text { niger }\end{array}$ & $\begin{array}{l}\text { Aspergillus } \\
\text { flavus }\end{array}$ & Control & Mean \\
\hline Abhaya & 0.162 & 0.167 & 0.219 & $0.183^{b}$ & 10.98 & 11.73 & 19.87 & $14.19^{c}$ \\
\hline Amaravati & 0.155 & 0.176 & 0.243 & $0.191^{c}$ & 9.89 & 11.58 & 22.16 & $14.54^{\mathrm{d}}$ \\
\hline Chitravati & 0.169 & 0.168 & 0.209 & $0.182^{\mathrm{b}}$ & 11.29 & 11.74 & 19.02 & $14.02^{\mathrm{c}}$ \\
\hline Dharani & 0.166 & 0.165 & 0.184 & $0.172^{\mathrm{a}}$ & 10.29 & 10.53 & 16.15 & $12.32^{\mathrm{a}}$ \\
\hline Haritandhra & 0.175 & 0.185 & 0.221 & $0.194^{c}$ & 11.78 & 12.82 & 20.01 & $14.87^{\mathrm{e}}$ \\
\hline ICGV 00350 & 0.139 & 0.174 & 0.206 & $0.173^{\mathrm{a}}$ & 9.39 & 12.05 & 18.77 & $13.40^{\mathrm{b}}$ \\
\hline Kadiri 6 & 0.192 & 0.193 & 0.241 & $0.209^{e}$ & 13.36 & 13.78 & 21.77 & $16.30^{\mathrm{g}}$ \\
\hline Kadiri 9 & 0.198 & 0.201 & 0.253 & $0.217^{\dagger}$ & 13.89 & 14.49 & 22.94 & $17.11^{\mathrm{h}}$ \\
\hline Narayani & 0.225 & 0.223 & 0.264 & $0.237^{g}$ & 15.64 & 15.89 & 24.49 & $18.67^{\mathrm{i}}$ \\
\hline TAG 24 & 0.222 & 0.220 & 0.266 & $0.236^{9}$ & 18.57 & 18.59 & 26.02 & $21.06^{j}$ \\
\hline TCGS 1073 & 0.246 & 0.245 & 0.306 & $0.266^{\mathrm{h}}$ & 17.41 & 17.52 & 28.05 & $20.99^{j}$ \\
\hline TCGS 1616 & 0.164 & 0.212 & 0.234 & $0.203^{d}$ & 11.44 & 15.07 & 21.31 & $15.94^{f}$ \\
\hline TCGS 1694 & 0.182 & 0.183 & 0.247 & $0.204^{d}$ & 1.65 & 12.95 & 22.52 & $16.04^{\mathrm{fg}}$ \\
\hline \multirow[t]{2}{*}{ Mean } & $0.184^{\mathrm{A}}$ & $0.193^{\mathrm{B}}$ & $0.238^{c}$ & & $12.81^{\mathrm{A}}$ & $13.75^{\mathrm{B}}$ & $21.78^{\mathrm{C}}$ & \\
\hline & G & \multicolumn{2}{|c|}{$\mathrm{T}$} & $\mathrm{GxT}$ & $\mathrm{G}$ & \multicolumn{2}{|c|}{$\mathrm{T}$} & GxT \\
\hline SEm & 0.00093 & \multicolumn{2}{|c|}{0.000445} & 0.002 & 0.106 & \multicolumn{2}{|c|}{0.0507} & 0.183 \\
\hline$C D(p=0.05)$ & 0.00234 & \multicolumn{2}{|c|}{0.001839} & 0.004 & 0.266 & \multicolumn{2}{|c|}{0.2096} & 0.443 \\
\hline CV (\%) & \multicolumn{3}{|c|}{1.566} & & & \multicolumn{2}{|c|}{2.272} & \\
\hline
\end{tabular}

*Values in the parenthesis indicate angular transformed values.

*Values followed by same alphabet in the same column do not differ significantly at $5 \%$ level of significance.

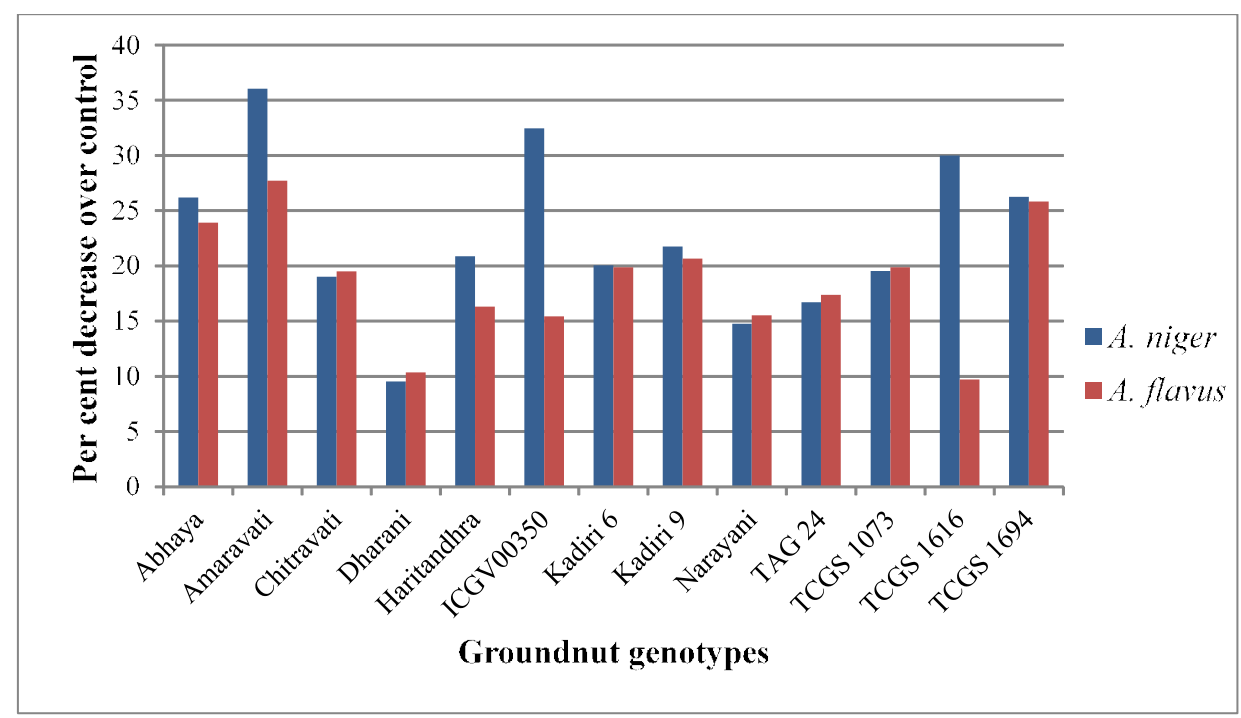

Fig 4: Per cent decrease in seedling dry weight over control due to Aspergillus spp. 


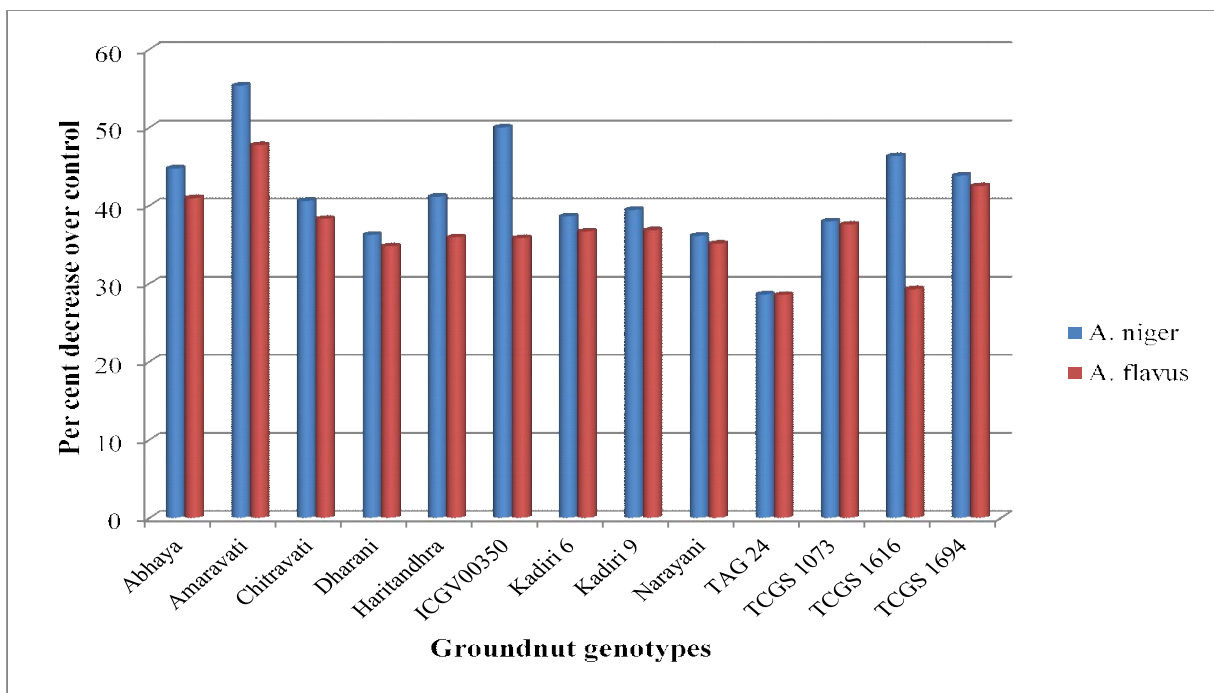

Fig 5: Per cent decrease in seedling vigour index II over control due to Aspergillus spp.

followed by TCGS 1616 (25.84\%). The minimum per cent reduction in seedling dry weight due to $A$. nigerwas recorded in Dharani $(9.54 \%)$ while due to $A$. flavus was recorded in TCGS 1616 (9.71) (Fig 4).

The reduction in seedling dry weight might be due to the utilization of energy rich compounds by the fungi which are otherwise translocated to the seedling for dry matter accumulation.

\section{Seedling vigour index II}

Significant reduction in seedling vigour index II was found in seeds inoculated with both $A$. niger and $A$. flavus. The seedling vigour index II was in the range of 10.53 (Dharani) and 18.59 (TAG 24) in seeds inoculated with $A$. flavus and between 9.39 (ICGV 00 350) and 18.57 (TAG 24) in seeds inoculated with $A$. niger as against 16.15 (Dharani) and 28.05 (TCGS 1073) in control (Table 2).

The average seedling vigour index decreased from 21.78 in control to 13.75 and 12.81 in $A$. flavus and $A$. niger inoculated seed, respectively. The maximum per cent reduction in seedling vigour index II due to $A$. niger was recorded in Amaravati (55.34\%) followed by ICGV 00350 (50.01\%). The maximum per cent reduction in seedling vigour index II due to $A$. flavus was recorded in Amaravati (47.72) followed by TCGS 1694 (42.49). The minimum per cent decrease in seedling vigour index II was recorded in TAG 24 in both $A$. niger (28.62) and $A$. flavus (28.57) inoculated seed (Fig 5).

Reduction in seedling dry weight was observed earlier in maize due to $A$. flavus (Paul, 1991) and in soybean due to A. niger (Haikal, 2008). Decrease in seedling dry weight of groundnut was reported due to $A$. niger (Rohtas et al. 2016).

Seed treatment with carbendazim, tebuconazole, carboxin+thiram reduced infection by collar rot pathogen, A. niger was observed by Kumari et al. (2016). Hence seed dressing with appropriate fungicides is suggested to protect groundnut from seed borne Aspergillus spp.

\section{CONCLUSION}

$A$. niger and $A$. flavus caused maximum per cent reduction in germination, seedling length and seedling vigour index I in groundnut varieties viz., Amaravati, TCGS 1616 and TCGS 1616. Amaravati also recorded maximum per cent reduction in seedling dry weight and seedling vigour index II due to inoculation of seed with $A$. niger and $A$. flavus. Protection with seed dressing fungicides like tebuconazole or carbendazim is important for raising healthy crop.

\section{REFERENCES}

Abdul-Baki, A.A. and Anderson, J.P. (1973). Vigour determination in soybean seed by multiple criteria. Crop Science. 13: 630-633.

Akonda, M.R., Yasmin, M. and Hossain, I. (2016). Incidence of seedborne mycoflora and their effects on germination of maize seeds. International Journal of Agronomy and Agricultural Research. 8(1): 87-92.

Begum, A.M.J., Balamurugan, P., Vanangamudi, K. and Prabakar, K. (2013). Establishing seed standard for seed health test in groundnut (Arachis hypogaea L.) for Aspergillus flavus. African Journal of Agricultural Research. 8(38): 4839-4848.

Deepavali, D.S. and Nilima, K.W. (2014). Toxic potential of $A$. niger metabolites on germination and seedling growth of maize grains. Journal of Chemical, Biological and Physical Sciences. 5(1): 501-510.

Haikal, N.Z. (2008). Effect of filtrates of pathogenic fungi of soybean on seed germination and seedling parameters. Journal of Applied Sciences Research. 4(1): 48-52.

Harman, G.E. and Pfleger, F.L. (1974). Pathogenicity and infection sites of Aspergillus species in stored seeds. Phytopathology. 64: $1339-1344$.

IOPEPC, Survey of Groundnut Crop, Kharif-2017. Indian Oilseeds and Produce Export Promotion Council, Mumbai, Maharastra.

International Rules for Seed Testing. (2015). International Seed Testing Association, Bassersdorf, Switzerland. 
Janardhan, A., Subramanyam, D., Praveen Kumar, A., Reddi Pradeep M. and Narasimha, G. (2011). Aflatoxin Impacts on Germinating Seeds. Annals of Biological Research. 2 (2): 180-188.

Kakde, R.B. and Chavan, A.M. (2010). Determination of Toxicity of some Fungal Metabolites on Seed Germination and Pigment Leaching. Journal of Ecobiotechnology. 2(6): 46-55.

Kumari, M., Singh, M., Godika, S., Choudhary, S. and Sharma, J. (2016). Effect of different fungicides, plant extracts on incidence varietal screening against collar rot of groundnut (Arachis hypogaea L.) caused by Aspergillus niger van Tiegham. The Bioscan. 11 (4): 2835-2839.
Paul, M.C. (1991). Studies on seed fungi of maize-biochemical changes in relation to fungal infection. Ph. D thesis. Northeastern hill university, Shillonog.

Reddy, Y.T.N. and Khan, M.M. (2001). Effect of osmopriming on germination, seedling growth and vigour of khirni (Mimusops hexandra) seed. Seed Research. 29(1): 24-27.

Rohtas, H.S., Saharan, R. and Rathi, A.S. (2016). Effect of Aspergillus niger on seed germination and seedling vigor of groundnut genotypes. Research in Environment and Life Sciences. 9(9): 1157-1159.

Sauer, D.B. (1988). Effects of fungal deterioration on grain: Nutritional value, toxicity, germination. International Journal of Food Microbiology. 7: 267-275. 